Jurnal Office: Jurnal Pemikiran Ilmiah dan Pendidikan Administrasi Perkantoran

Vol. 6, No. 2, July-December 2020, Page 143-152

Homepage: http://ojs.unm.ac.id/jo

\title{
Records Management at PT. Bank Sulselbar Jeneponto Branch
}

\author{
Risma Niswaty ${ }^{1}$, Muh. Amin ${ }^{2}$, Haedar Akib $^{3}$, Jamaluddin \\ ${ }^{1,2,3,4}$ Universitas Negeri Makassar \\ Email: rismaniswaty@unm.ac.id
}

\begin{abstract}
Records management plays an important role in the running of an organization. This study aims to determine the description of archival management at PT. Bank Sulselbar Jeneponto Branch. To achieve this goal, the Researcher determined 3 (three) informants, namely: Operations Section Leader, Operational Assistant, and Administrative Assistant. This type of research and the approach used is descriptive qualitative. Collecting data through interview techniques, observation, and documentation. Data analysis techniques are carried out through data collection, data condensation, data presentation, data verification/conclusions. The results showed that archival management at PT. Bank Sulselbar Jeneponto Branch has been managed optimally. This can be seen from the indicators of the stages of receiving archives, the stages of archive storage, the stages of maintaining and securing archives, the stages of shrinking archives, and the stages of destroying archives that have fulfilled almost all aspects of the five stages. Evidenced by the management of records at PT. Bank Sulselbar Jeneponto Branch is adjusted to Standard Operating Procedures and archives that are easy to find as well as an archival storage system using a number system.
\end{abstract}

Keywords: Management, archives, archiving

\section{INTRODUCTION}

In the era of globalization 4.0, currently one of the administrative activities carried out in an organization is archiving (Hossain, Hossain, and Grabher 2020; Kiklhorn et al. 2020; Oyugi et al. 2020). Archiving is an office or administrative job that is mostly carried out by every business entity, both government and private business entities (Demirtel and Bayram 2014; Lee and Lee 2009; Mokhtar and Yusof 2016). An office is a central place for activities and information providers to support the ease of carrying out activities in all fields (Ayu et al. 2019; Nasrullah, Siraj, and Arhas 2020). Each office has data and information which is usually stored in archives. because archives are evidence and records of activities or transactions starting from front activities to decision making activities.

Berdasarkan (Undang-undang Nomor 43 Tahun 2009 tentang Kearsipan 2009), Article 1 paragraphs 1 and 2 explain that: archives are records of activities or events in various forms and media by developments in information and communication technology that are made and accepted by state institutions, regional governments, educational institutions, companies, political organizations, social organizations, and individuals in the implementation of social, national and state life.

Records management plays an important role for the running of an organization, namely as a source of information (Brunskill 2012; Sundqvist and Svärd 2016; Van Wingen, Hathorn, and Sprehe 1999) and as an organizational memory center that can be useful for material assessment, decision making and formulating policies (Benson 2011; J. M. Ryan 2017), or the preparation of development programs from the associated organizations (Kiklhorn et al. 2020). The purpose of the archive is said to be a source of memory for an organization because the archive itself has useful information material and if necessary it must be quickly and accurately presented at any time to facilitate decision making..

In an administrative activity, the archive is a very important part of the job. But many people think 


\section{4| Jurnal Office: Jurnal Pemikiran Ilmiah dan Pendidikan Administrasi Perkantoran}

Vol. 6, No. 2, July-December 2020, Page 143-152

that filing work is a boring activity and tends not to be too important. However, we see the region's role, this archive activity is very important for the office.

Good archive management requires a systematic and effective arrangement of archives so that it is useful so that those who need archives can be presented quickly and precisely to those who need them. (Saputri, Tambe, and Darwis 2015). Realizing good archive management requires creative and insightful human resources who can carry out tasks optimally. However, in managing records, it is not easy, some problems arise which cause the management of records to be less than optimal. Kerasipan problems are things that require special attention from an office in its implementation because archives have a useful value to provide information in carrying out tasks in the future (Gunnlaugsdottir 2008; Kautto and Henttonen 2020; J. M. Ryan 2017).

\section{METHOD}

The variable in this study is a single variable, namely Records Management at PT. Bank Sulselbar Jeneponto Branch. This study uses a qualitative approach. The type of research used is descriptive research, requiring data derived from individual or informant information. The research that the author did last for 2 months located at PT. Bank Sulselbar Jeneponto Branch. Resource persons used as informants in this study amounted to 3 employees who work at PT. Bank Sulselbar Jeneponto Branch named Alauddin S.E as Head of Operations Section, Fadlilah Qurani Anwar as Operations Assistant and Harman Pious as Administrative Assistant. Sources of data in this study were obtained from observations and documentation or pictures/photos related to the implementation of this research activity. In this study, the data collection techniques used were observation, interview, and documentation techniques.

Checking the validity of the data can be done by using triangulation techniques and member checks. Triangulation of sources to test the validity of the data was done by checking the data obtained from several sources. Technique triangulation to assess the validity of the data is done by checking the data from the same source with different techniques. The validity of data is also often affected by time. Therefore, to test the validity of the data, it is done by checking using interviews, observations, and other techniques in different times and situations. Member check is the process of checking the data obtained by the data provider. Member check aims to find out how far the data obtained is by what is provided by the data provider, so that the information obtained and which will be used in writing reports is by what is meant by data sources or informants.

The data analysis technique carried out by researchers is the Miles and Huberman Model (Arhas and Suprianto 2020) which includes data collection, data condensation, data presentation, and drawing and verification of conclusions. Data collection was carried out from the preparation of the research to the implementation of the interview. Data condensation refers to the processes of selecting or selecting, focusing, simplifying, and changing the data contained in field notes, interview traces, documents, and empirical data that have been obtained. Data presentation is an arrangement, a collection of information that has been narrowed down so that conclusions can be drawn. Decision making is a process in which data is interpreted from the start of the collection, accompanied by pattern making and descriptions or explanations. Decision making is evidence of the research carried out.

\section{RESULT AND DISCUSSION}

To find out the extent of archiving management at PT. Bank Sulselbar Jeneponto Branch, processing and presenting the data obtained during the research is carried out. The first data collection technique was carried out by conducting interviews with informants who worked at PT. Bank Sulselbar Jeneponto Branch. The data presented were obtained through direct interviews with the head of the 
operational section of the general field of finance as the main informant and several employees as supporting informants.

The theory used is the theory (Sugiarto, R Silintowe, and Kartika 2013) regarding archiving management whose indicators consist of: receipt of archives, archive storage, maintenance and security of archives, archive shrinkage, and destruction of archives.

All data collected will be presented in descriptive form, namely presenting the data obtained in the form of explanation through word descriptions so that they become sentences that are easy to understand. For more details, it will be described in detail based on the results of interviews obtained from each indicator.

\section{Receipt of Archives}

In the activity of receiving archives, a special unit is carried out as the center for receiving, registering letters that have been received by an agency then submits and manages the letter according to the procedure.

Based on the results of interviews conducted with Mr. Alauddin, it is known that incoming letters are sorted first, then the letters are organized through administration. Regarding the procedures in managing records at PT. Bank Sulselbar Jeneponto Branch is based on procedures, Suppose there is an archive in the financial section, the general section, the core part of each of which manages files in an organized and neat manner. Each section is responsible for the archive. When the archives are several years old we secure them in the archive warehouse.

According to the results of the interview with Ms. Fadlilah, she explained that if there were letters that came in, they were directly recorded or agendas. For the process of receiving the incoming letter, first from the agency then the letter is brought to the general section then the general section agendas the letter, after being agenda it is taken to the branch leader for disposition, then directed whether the letter is to be given to services, to operations or marketing. PT. Bank Sulselbar Jeneponto Branch has a fixed procedure in managing the archives in the Bank, for example, if there is an incoming letter, it is agenda, then taken to the branch leader, then the disposition is then directed to do what to do with this letter and then stored in the archive.

According to the results of the interview with Mr. Harman, explaining the archive of incoming letters that we received. Regarding the process of receiving the incoming letter, we receive an incoming letter from outside through Security then the letter is agenda, meaning that the number is given to the incoming letter and then forwarded to the branch leader, then the branch leader disposes of the letter regarding the follow-up letter where the letter is going. Regarding the filing management procedure at PT. Bank Sulselbar Jeneponto Branch has an SOP (Standard Operating Procedure) so after the letter is disposed of by the branch leader, where will it be, who keeps all of it there is an SOP (Standard Operating Procedure).

Based on the above opinion, it is concluded that the archive acceptance activity starts from the incoming letter at PT. Bank Sulselbar Jeneponto Branch was immediately recorded without any sorting on letters and regarding procedures for managing records at PT. Bank Sulselbar Jeneponto Branch already exists and standard operating procedures have been established.

\section{Archive Storage}

Archival storage activities are carried out by storing archives using an archive storage system to make it easier to find documents that have been stored if needed at any time quickly.

Based on the results of an interview conducted with Mr. Alauddin, it was explained that we had an archive warehouse. We pack the archives in this warehouse in dos form and note them in their respective 


\section{6| Jurnal Office: Jurnal Pemikiran Ilmiah dan Pendidikan Administrasi Perkantoran}

Vol. 6, No. 2, July-December 2020, Page 143-152

sections. For example, financial records, marketing records, service records, there are certain rooms and all the files are neatly arranged. Also, in archive storage, some are responsible for that archive. Archives that have been for years, for example, the 2018 archives and 2019 archives are arranged in an archive warehouse and then accounted for by employees about the arrangement of archives in their respective sections in the warehouse. So we have a warehouse in the back consisting of several shelves that are devoted to archives, so we separate each archive, starting from the archives from the financial department, the marketing department, the service section, the teller section to the cash evidence files, there is accountability for everything. Regarding the archive storage system based on the date, month, and year system.

According to the results of an interview with Mrs. Fadlilah, explaining the equipment used in storing archives using folders. The archives are put into the folder and then stored in the iron cupboard and locked. For steps to find archives, first look at the letter agenda on the computer if it is not found on the computer, then we will look for it based on the month of the incoming letter, then when it is found, immediately look for it in the warehouse because all archives must have been stored in the warehouse if it had been a long time. at PT. Bank Sulselbar Jeneponto Branch in storing archives using a dating system.

According to the results of an interview with Mr. Harman, explaining that for now, we can protect the meaning of our archives at PT. Bank Sulselbar Jeneponto Branch physical archives are neatly arranged and the files are grouped manually and then stored based on the classification of the letter files. For example, grouping based on the nature of the letter. There are also archived digitally, for example, the letter is scanned and then the soft file is stored in a folder or copied onto the hard disk. For a system of grouping letters such as letters that are confidential, as well as in ordinary nature, they are stored based on the date.

Based on the above opinion, it is concluded that the archive storage activities at PT. Bank Sulselbar Jeneponto Branch use equipment such as folders and safes and for old archives placed in a warehouse of archives, these files are neatly arranged on a shelf and are also packaged in boxes and for archives that are managed in digital form of documents or letters scanned first and then put together in a folder after that it is stored on the computer and just in case the soft files that have been in the folder are copied again to the hard disk.

\section{Archive Maintenance and Security}

Maintenance and safeguarding activities are efforts to safeguard archives so that their physical condition is not damaged and ensure the survival of archives from unwanted destruction as long as they have useful value. Archival security is an effort to protect archived objects from being lost and so that the contents and information are not known by unauthorized persons.

Based on the results of interviews conducted with Mr. Alauddin, explaining that if we want the archives to be maintained and not quickly eaten by termites, we usually pack these files in boxes that already contain some kind of anti-termite medicine so that the archives don't get damaged quickly. So the archive maintenance at PT. Bank Sulselbar Jeneponto Branch is well maintained and guarded because the file is a paper file containing information and one day it will be needed. Regarding archive security, this task is given to the person in charge of the archive warehouse. So there are employees who are assigned to the preparation of the existing archives in the warehouse and are responsible for securing the archives.

According to the results of an interview with Mrs. Fadlilah explaining the maintenance of archives at PT. Bank Sulselbar Jeneponto Branch, if there is an important letter, is always entered in certain places such as official travel documents, there are separate posts so that it does not happen, for example, being scattered or joining other documents. The fear is if the letter joins we will be confused and do not know which letter it is, so it must be sorted before being filed so that it will be put into their respective posts. 
Safeguarding the archive itself, for example, securing important documents has its place in the cupboard. If it's been a long time and no longer searched for or in the past five years, it is stored in the archive warehouse.

According to the results of an interview with Mr. Harman regarding archival storage, it was explained that the guarding and securing of the archive was not one person but a team, there were Security and Police who guarded the archives of PT. Bank Sulselbar Jeneponto branch in the warehouse of archives day and night. Not even an archive warehouse, but all areas in PT. Bank Sulselbar Jeneponto Branch.

Based on the informant's explanation, it was concluded that the activities of maintaining and securing archives at PT. Bank Sulselbar Jeneponto Branch are already good because the archives in PT. Bank Sulselbar Jeneponto Branch is really well maintained and for very tight security because it is closely monitored and guarded by the Bank Security and Police morning, afternoon and evening.

\section{Archive Shrinkage}

Based on the results of interviews conducted with Mr. Alauddin, he explained that the archive has its time, for example, the archive is 15-20 years old, we will write to the head office and then report regarding this archive. So the archive warehouse is limited, years can't store archives in the warehouse. So when we report the age of this archive and even if there is an agreement from the center that the archives need to be destroyed because they are past their period and are no longer used, meaning that they are of no use, then we can destroy the archive.

According to the results of the interview with Ms. Fadlilah, she explained that archival shrinkage can be done if it has been 5 years ago. Based on the informant's explanation, it was concluded that the shrinkage of the archives at PT. Bank Sulselbar Jeneponto Branch must go through related reports and the archive is of age or period has passed and is no longer needed.

\section{Archive Destruction}

Based on the results of interviews conducted with Mr. Alauddin, he explained that there is a procedure for destroying archives. not necessarily destroyed of our own accord. Still, we tell the management. Suppose it is an archive, so we must explain it related to reporting and ask for approval and we must also be accountable for how to explain the contents of the letter if the archive is so many years old and in this condition, it means that the condition can still be used but related to that interest, $10 \%$ of its importance is left. doesn't matter because it's its time. that's the rule regarding the extermination rule. the destruction of the archives itself is usually 15-20 years old.

According to the results of the interview with Mrs. Fadlilah, explaining that the first archive destruction procedure is made a report based on the letter-number so it is clear which letter is destroyed, and usually, the archive is destroyed when it is 5 years old.

According to the results of an interview with Mr. Harman, related to archive storage, it was explained that the destruction of the archives had an SOP (Standard Operating Procedure). Certain archives are destroyed after the age of 20,10 years, even under the age of 10, for example, archives that are 20 years old such as proof of transactions, proof of cash, proof of book-entry can be destroyed at least 20 years. The archives are destroyed, meaning that they do not lose traces because before they are destroyed, data is recorded, then a list is made, then an official report is made so that the files that had been destroyed still have the data. If it has fulfilled the procedure, then the archives will be destroyed by burning them and they can also be buried on the ground. However, the traces of the archives that have been destroyed are not completely lost because previous records have been made of the archives that will be destroyed. 
148| Jurnal Office: Jurnal Pemikiran Ilmiah dan Pendidikan Administrasi Perkantoran

Vol. 6, No. 2, July-December 2020, Page 143-152

Based on the informant's explanation, it was concluded that the archival destruction activities at PT. Bank Sulselbar Jeneponto Branch are by the procedures previously established. Regarding the age of the destroyed archives, it is around 20 years, 10 years, even less than 10 years from its time. Even though the archives have been destroyed, it does not mean that the traces have been lost because before they are destroyed, records are recorded for the files that will be destroyed.

\section{Discussion}

\section{Receipt of Archives}

Archives Reception Activities at PT. Bank Sulselbar Jeneponto Branch has been carried out properly by the procedure if there is an incoming letter it is immediately received, recorded in an agenda, then disposed of by the branch leader after it is stored. This is in line with the theory of Sugiarto \& Wahyono (2015), Archive Receiving is an activity carried out by a special unit as a receiving center, registering letters that have been received by an agency then submitting and managing letters according to procedures. Archives Receipt at PT. Bank Sulselbar Jeneponto Branch has been carried out properly according to the procedure. other than that it is associated with an opinion (Kautto and Henttonen 2020), After the letter is received, it is necessary to carry out several steps, namely receiving, sorting, recording, scheduling incoming mail, directing and forwarding, delivering letters, storing files or archives of incoming mail. Based on this opinion, it is in line with the process of receiving incoming letters at PT. Bank Sulselbar Jeneponto Branch with the process of receiving letters, is recorded in the agenda book then forwarded to the branch leadership to be disposed of after that the letter is stored.

\section{Archive Storage}

Archives at PT. Bank Sulselbar Jeneponto Branch in storing archives using a numbering system to make it easier to find and search if at any time the archive will be needed. Besides that, the archives at PT. Bank Sulselbar Jeneponto branch is stored in a cupboard, some of which are stored in an archive warehouse, and stored in digital form. This is in line with the theory of Sugiarto \& Wahyono (2015), archive storage is the activity of storing archives using an archive storage system so that easy storage can be created and the discovery of documents that have been stored can be found quickly whenever the document is needed. This is also in line with the opinion Tambe in (Saputri, Tambe, and Darwis 2015) archive storage system, namely the chronological system, alphabet system, geographic system, number system, and subject system. While the archives in PT. Bank Sulselbar Jeneponto Branch in storing archives using a numbering system

\section{Archive Maintenance and Security}

Archives at PT. Bank Sulselbar Jeneponto Branch, before being stored in the warehouse, is packed in the form of a dosage that already contains some kind of anti-termite medicine so that the archives do not get damaged quickly by termites. Archive security at PT. Bank Sulselbar Jeneponto Branch, this task is given to employees who are responsible for the preparation of the existing archives in the warehouse and are also responsible for securing these records.

This is in line with the theory of Sugiarto \& Wahyono (2015), Archive maintenance is an effort to safeguard archives so that their physical condition is not damaged and ensure the survival of archives from unwanted destruction as long as they have useful value. Meanwhile, safeguarding archives is an effort to protect archived objects from being lost and so that the contents and information are not known by unauthorized persons. And also as stated by According (Özdemirci 2008) that archive maintenance is an effort to safeguard archives so that they are well maintained, thus preventing possible damage and loss 
of archives. Archives at pt. Bank Sulselbar Jeneponto branch is always well maintained and is ensured that its physical and contents are always maintained and not damaged. While (Wursanto 1991) Archive security concerns in terms of information and safeguarding archives from a physical perspective. Security archives in terms of physical means that if they are physically preserved, their contents are preserved and vice versa. Likewise with archive security at PT. Bank Sulselbar Jeneponto Branch which is very safe and closely guarded can be proven by the presence of a security guard who guarded the police..

\section{Archive Shrinkage}

Archive shrinkage activities at PT. Bank Sulselbar Jeneponto Branch is carried out according to the procedure so that the archives to be depreciated are known to the head office that the archives have no longer use value and are suitable for destruction.

This is in line with the theory of Sugiarto \& Wahyono (2015), Archive shrinkage is an activity to reduce the number of archives that are managed through activities of transferring, handing over to other parties, and destruction. The transfer is an internal action meaning that it is still ongoing within the company environment. Transfer of documents is internal, namely from the management unit to the archiving unit within the company. Meanwhile, submission is external action, namely from the company to the national archive. Destruction is an attempt to make existing archives non-existent or to make archives unrecognizable. Meanwhile, according to (Undang-undang Nomor 43 Tahun 2009 tentang Kearsipan 2009) Archive shrinkage is carried out when the archive has expired its retention period (cut off).

\section{Archive Destruction}

Archive Destruction Activities at PT. Bank Sulselbar Jeneponto Branch is known that it is carried out according to the procedure. Regarding the archives to be destroyed must be submitted to management and explain about the reporting of the archives concerning the age of these archives which are up to 10 or 20 years and have no use-value or interest in the archives themselves. After that, ask for approval, after being approved, then an official report is made based on the letter-number so it is clear which letter was destroyed. So it is destroyed by burning and piled up on the ground while recording and documenting. This is in line with the theory of Sugiarto \& Wahyono (2015), Archival destruction means removing the existence of an archive from a storage area. Destruction of archives is the act or activity of physically destroying archives that have ended their function and have no more useful value. The destruction of the archives is carried out so that the identity of the relevant archives is completely lost. The implementation of the destruction of archives can be done in three ways: Burning, Destruction with chemicals, Recording of archives with an archive enumeration machine. This is in line with the opinion of (Benson 2011) that archive destruction is one of the activities of shrinking archives which aims to reduce the number of archives. Archives that are to be destroyed must-have criteria including having no use-value, have expired their retention, and are certified as being destroyed based on JRA, there are no laws and regulations that prohibit and are not related to the completion of processes or cases.

\section{CONCLUSION}

Based on the formulation of the problem and the results of research conducted by the author on Archives Management at PT. Bank Sulselbar Jeneponto Branch, it is concluded that the Archive Management at PT. Bank Sulselbar Jeneponto branch is already good. In managing archives at PT. Bank Sulselbar Jeneponto Branch is also carried out according to a predetermined procedure. 
150| Jurnal Office: Jurnal Pemikiran Ilmiah dan Pendidikan Administrasi Perkantoran Vol. 6, No. 2, July-December 2020, Page 143-152

\section{REFERENCES}

Arhas, Sitti Hardiyanti, and Suprianto Suprianto. 2020. "The Effectiveness of 6M Implementation at Artebo MSME." Jurnal Ad'ministrare 6(2): 249-56.

Ayu, Asri, Risma Niswaty, Muh Darwis, and Sitti Hardiyanti Arhas. 2019. "Applying the Principles of Good Governance in the Efforts of Guiding Out-of-School Children at Social Service Offices Takalar Regency.” Jurnal Office 5(2): 51-58.

Benson, G A. 2011. "Business Management | Management Records and Analysis." In ed. John W B T Encyclopedia of Dairy Sciences (Second Edition) Fuquay. San Diego: Academic Press, 486-91. http://www.sciencedirect.com/science/article/pii/B9780123744074000601.

Brunskill, Charlotte. 2012. "7 - Developing a File Plan, Retention Schedule and Records Management Programme." In Chandos Information Professional Series, eds. Charlotte Brunskill and Sarah R B T - Records Management for Museums and Galleries Demb. Chandos Publishing, 137-71. http://www.sciencedirect.com/science/article/pii/B9781843346371500077.

Demirtel, Hakan, and Özlem Gökkurt Bayram. 2014. "Efficiency of Electronic Records Management Systems: Turkey and Example of Ministry of Development." Procedia - Social and Behavioral Sciences 147: 189-96. http://www.sciencedirect.com/science/article/pii/S1877042814040701.

Gunnlaugsdottir, Johanna. 2008. "Registering and Searching for Records in Electronic Records Management Systems." International Journal of Information Management 28(4): 293-304. http://www.sciencedirect.com/science/article/pii/S0268401208000145.

Hossain, Gaffar, Ishtia Zahir Hossain, and Günter Grabher. 2020. "Piezoresistive Smart-Textile Sensor for Inventory Management Record." Sensors and Actuators A: Physical 315: 112300. http://www.sciencedirect.com/science/article/pii/S0924424720307482.

Kautto, Tuija, and Pekka Henttonen. 2020. "Records Management as Invisible Work: A Study of Finnish Municipalities." Government Information Quarterly 37(4): 101460. http://www.sciencedirect.com/science/article/pii/S0740624X1930317X.

Kiklhorn, David, Michael Wolny, Maximilian Austerjost, and Alexander Michalik. 2020. "Digital Lifecycle Records as an Instrument for Inter-Company Knowledge Management." Procedia CIRP 93: 292-97. http://www.sciencedirect.com/science/article/pii/S2212827120306715.

Lee, Kyong Rae, and Kwang-Suk Lee. 2009. “The Korean Government's Electronic Record Management Reform: The Promise and Perils of Digital Democratization." Government Information Quarterly 26(3): 525-35. http://www.sciencedirect.com/science/article/pii/S0740624X09000641.

Mokhtar, Umi A, and Zawiyah M Yusof. 2016. "Records Management Practice: The Issues and Models for Classification." International Journal of Information Management 36(6, Part B): 1265-73. http://www.sciencedirect.com/science/article/pii/S026840121630514X.

Nasrullah, Muh, Muhammad Luthfi Siraj, and Sitti Hardiayanti Arhas. 2020. "Intensification of Land and Building Tax Collection in The Barru Regency Revenue Service.” In 3rd International Conference on Social Sciences (ICSS 2020), Atlantis Press, 570-73.

Oyugi, Boniface et al. 2020. "Improving the Management of Hypertension and Diabetes: An Implementation Evaluation of an Electronic Medical Record System in Nairobi County, Kenya." $\begin{array}{llllll}\text { International Journal of } & \text { Medical } & \text { Informatics } & 141 \text { : } & 104220 .\end{array}$ 
http://www.sciencedirect.com/science/article/pii/S1386505620301404.

Özdemirci, Fahrettin. 2008. "Government Records and Records Management: Law on the Right to Information in Turkey." Government Information Quarterly 25(2): 303-12. http://www.sciencedirect.com/science/article/pii/S0740624X06001717.

Ryan, John M. 2017. “Chapter 4 - System Management and Record Keeping.” In ed. John M B T - Guide to Food Safety and Quality During Transportation (Second Edition) Ryan. Academic Press, 103-49. http://www.sciencedirect.com/science/article/pii/B9780128121399000046.

Saputri, Imelda Alwiyah, M Nippi Tambe, and Muhammad Darwis. 2015. "Efektifitas Pengelolaan Kearsipan Pada Kantor Sekretariat Daerah Kabupaten Gowa Provinsi Sulawesi Selatan." Jurnal Office 1(2): 153-59.

Sugiarto, Agus, Yunita B R Silintowe, and Lucia N Kartika. 2013. "Pengembangan Sistem Kearsipan Elektronik Berbasis.” Jurnal Teknologi Informasi-Aiti.

Sundqvist, Anneli, and Proscovia Svärd. 2016. "Information Culture and Records Management: A Suitable Match? Conceptualizations of Information Culture and Their Application on Records Management." International Journal of Information Management 36(1): 9-15. http://www.sciencedirect.com/science/article/pii/S0268401215000870.

Undang-undang Nomor 43 Tahun 2009 tentang Kearsipan. 2009. Arsip Nasional Republik Indonesia.

Van Wingen, Rachel Senner, Fred Hathorn, and J.Timothy Sprehe. 1999. "Principles for Information Technology Investment in u.s. Federal Electronic Records Management." Journal of Government Information 26(1): 33-42. http://www.sciencedirect.com/science/article/pii/S1352023798000860.

Wursanto, I. 1991. Kearsipan. Kanisius. https://books.google.co.id/books?id=SIThAAAACAAJ. 
$152 \mid$ Jurnal Office: Jurnal Pemikiran Ilmiah dan Pendidikan Administrasi Perkantoran Vol. 6, No. 2, July-December 2020, Page 143-152 